\title{
Faktor Risiko Terhadap Kejadian Gangguan Koagulasi pada Neonatus
}

\author{
Ima Sonia, Kamilah Budhi, ${ }^{1}$ Moedrik Tamam, ${ }^{1}$ Indrayani Padmosoedarso ${ }^{2}$ \\ ${ }^{1}$ Departemen Ilmu Kesehatan Anak Fakultas Kedokteran Universitas Diponegoro/RSUP Dr. Kariadi, Semarang ${ }^{2}$ RS Telogorejo, Semarang
}

Latar belakang. Perdarahan pada neonatus merupakan $10 \%$ penyebab kematian di NICU. Deteksi awal perdarahan sering terlambat sebab tidak semua neonatus dengan pemanjangan faktor koagulasi bermanifestasi perdarahan. Diperlukan tindakan deteksi dini pada neonatus dengan faktor risiko penyakit perdarahan (skrining prothrombin time (PT) dan partial thromboplastin time with kaolin (PTTK)).

Tujuan. Meneliti faktor maternal dan neonatal terhadap gangguan koagulasi pada neonatus.

Metode. Studi kasus kontrol dengan 45 subjek pada kelompok kasus dengan pemanjangan studi koagulasi (PT dan PTTK) dan 45 subjek pada kelompok kontrol dengan studi koagulasi normal di RSUP Dr. Kariadi Semarang dan RS Telogorejo (Semarang Medical Centre) antara tahun 2016-2017. Faktor risiko didapat dari anamnesis dan data rekam medik. Analisis data menggunakan chi square lanjut analisis multivariat regresi logistik ganda (Backward Wald).

Hasil. Preeklampsia (RO 4,26; p=0,018) dan Kecil Masa Kehamilan (KMK) (RO 4,52; p=0,042) adalah faktor risiko signifikan terhadap pemanjangan PT dan PTTK neonatus. Faktor risiko maternal dan neonatal lain yaitu korioamnionitis, obat dikonsumsi ibu (antikoagulan /antikonvulsan), Bayi Kurang Bulan, asfiksia, sepsis, penyakit hati tidak terbukti sebagai faktor risiko pemanjangan PT dan PTTK.

Kesimpulan. Preeklampsia dan KMK merupakan faktor risiko signifikan secara statistik terhadap pemanjangan PT dan PTTK pada neonatus. Preeklampsia adalah faktor risiko paling kuat berpengaruh terhadap pemanjangan PT dan PTTK pada neonatus. Sari Pediatri 2021;23(3):164-70

Kata kunci: faktor risiko maternal, faktor risiko neonatal, pemanjangan studi koagulasi

\section{Risk Factor of Coagulation Disorder in Neonates}

Ima Sonia, Kamilah Budhi, ${ }^{1}$ Moedrik Tamam, ${ }^{1}$ Indrayani Padmosoedarso ${ }^{2}$

Background. Bleeding accounts for $10 \%$ of mortality in NICU. Generally, detection of bleeding in neonates is postponed because not all neonates have bleeding manifestations. Early detection of neonates with the risk factor of bleeding is mandatory (screening Prothrombin time (PT) and Partial Thromboplastin Time with kaolin (PTTK)).

Objective. To investigate maternal and neonatal risk factors of coagulation disorder in neonates.

Method. Case control study of 45 subjects in case group (prolonged PT and PTTK) and 45 subjects in control group (normal PT and PTTK) in Kariadi and Telogorejo Hospital (Semarang Medical Centre), in the year of 2016-2017. Risk factors were collected through anamnesis and medical record. Data analysis with Chi square continues with multivariate analysis with logistic regression Backward Wald.

Result. Preeclampsia (OR 4,26; p=0,018) and Small Gestational Age (SGA) $(\mathrm{OR} 4,52 ; \mathrm{p}=0$,042) are the significant risk factor of prolonged coagulation studies. Other maternal and neonatal risk factors including chorioamnionitis, anticonvulsant or anticoagulant which was taken by the mother, preterm, sepsis, asphyxia, liver disease are not presented as risk factor of prolonged coagulation studies.

Conclusion. Preeclampsia and SGA are the significant risk factor of prolonged coagulation studies in neonates. Preeclampsia is the strongest risk factor of prolonged PT and PTTK in neonates. Sari Pediatri 2021;23(3):164-70

Keywords: maternal risk factor, neonatal risk factor, prolonged coagulation studies

Alamat korespondensi: Ima Sonia. Bagian Ilmu Kesehatan Anak Fakultas Kedokteran Universitas Diponegoro/RSUP Dr. Kariadi Jl. Dr. Soetomo No.16. Semarang, Jawa Tengah. Email: dr.imasonia@gmail.com 
Ima Sonia dkk: Faktor risiko terhadap kejadian gangguan koagulasi pada neonatus

$\mathrm{H}$ emostasis adalah mekanisme tubuh untuk menghentikan perdarahan secara spontan. Beberapa sistem yang berperan dalam hemostasis adalah sistem vaskuler (vasokontriksi), trombosit (pembentukan gumpalan trombosit) dan pembekuan darah (pembentukan fibrin untuk menstabilisasi gumpalan trombosit). ${ }^{1}$ Faktor koagulasi disintesis secara independen, tidak melewati sawar plasenta, dipengaruhi oleh usia gestasi dan maturitas hati. ${ }^{2}$ Saat lahir, faktor kontak (prekursor thromboplastin (XI), Hageman (XII), kininogen) dan faktor dependen vitamin K, 50\% lebih rendah dari kadar dewasa, generasi thrombin lebih rendah 30-50\% dari dewasa. Pemeriksaan prothrombin time (PT), partial thromboplastin time (PTTK) dan thrombin time (TT) dapat memanjang pada neonatus, tetapi perdarahan tidak selalu terjadi karena terdapat kompensasi hemostasis, yaitu sistem fibrinolitik yang mengalami penurunan plasminogen $50 \%$ dari dewasa disertai peningkatan plasminogen activator inhibitor. Beberapa keadaan perinatal atau neonatal dapat menganggu keseimbangan ini dan meningkatkan risiko perdarahan atau pembentukan trombus 3,4

Pemeriksaan awal untuk menegakkan diagnosis pasien dengan gangguan koagulasi terdiri dari pemeriksan darah rutin, prothrombin time (PT) dan partial thromboplastin time (PTTK). Pemeriksaan PT mengevaluasi jalur ekstrinsik dan common pathway/ jalur klasik (gabungan jalur ekstrinsik dan intrinsik) pada proses koagulasi sehingga peningkatan PT mengindikasikan adanya gangguan fungsi tissue factor, faktor VII, X, V, II, dan I (dependen vitamin K). Pemeriksaan PTTK menilai fungsi jalur intrinsik dan common pathway sehingga dapat menilai defisiensi faktor XII, XI, IX dan VIII, X, V, II, I. ${ }^{5}$ Manifestasi perdarahan pada neonatus meliputi perdarahan tali pusat $(46.3 \%)$, hematoma dan ekimosis (44\%), perdarahan pada lokasi penyuntikan (8\%) dan sefalhematoma (6\%). ${ }^{6}$

Faktor risiko neonatal yang berpengaruh terhadap kejadian perdarahan meliputi Bayi Kurang Bulan (BKB), Kecil Masa Kehamilan (KMK), sepsis, asfiksia, perdarahan akibat defisiensi vitamin K (PDVK), penyakit hati, hemofilia, penyakit von Willebrand, kelainan perdarahan yang jarang terjadi (kelainan fibrinogen, defisiensi prothrombin, defisiensi faktor XIII) ${ }^{7,8,9}$ Faktor risiko maternal yang berpengaruh terhadap kejadian perdarahan neonatus, meliputi preeklampsia, plasenta abrupsio, korioamnionitis dan obat yang memengaruhi sintesis faktor koagulasi, yaitu antikonvulsan dan antikoagulan, hemofilia, penyakit von Willebrand, kelainan perdarahan yang jarang terjadi (kelainan fibrinogen, defisiensi prothrombin, defisiensi faktor XIII). ${ }^{8,9}$

Data dari National Centre for Health Statistic (NCHS), perdarahan neonatus termasuk peringkat keenam penyebab kematian pada bayi sebesar $10 \%{ }^{10,11}$ Maduhu $\mathrm{dkk}^{6}$ melaporkan kejadian perdarahan bayi usia gestasi kurang 28 minggu mencapai 10,7\%, 29\% di antaranya mengalami perdarahan berat. Perdarahan merupakan $10 \%$ penyebab kematian di NICU. ${ }^{10}$ Atas dasar kajian di atas, peneliti bertujuan untuk membuktikan faktor maternal dan neonatal sebagai faktor risiko gangguan koagulasi pada neonatus.

\section{Metode}

Jenis penelitian adalah penelitian observasional analitik dengan desain case control. Populasi penelitian adalah bayi yang dirawat di RSUP dr. Kariadi dan RS Telogorejo Semarang pada Januari 2016 hingga Januari 2017. Kriteria inklusi adalah bayi lahir tunggal, pemanjangan PT dan PTTK pada kelompok kasus dan pemeriksaan studi kogulasi normal pada kelompok kontrol. Kriteria eksklusi adalah bayi dengan sindrom, kelainan herediter, mendapat transfusi darah dan data tidak lengkap. Subyek yang memenuhi kriteria inklusi diberi penjelasan mengenai penelitian yang akan dilakukan dan menandatangani surat persetujuan untuk mengikuti penelitian.

Pengambilan subyek dilakukan secara consecutive sampling dengan besar subyek masing-masing kelompok 45. Studi koagulasi diperiksa dalam 24 jam setelah bayi lahir. Pemeriksaan PT dan PTTK menggunakan Sysmex CS-2100i dengan reagen Dade Inovin untuk PT dan Actin FSL untuk PTTK. Pemanjangan studi koagulasi didefinisikan dengan nilai rujukan PT $>11,3$ detik dan PTTK >30,6 detik. Uji statistik dengan menggunakan uji chi square yang bertujuan melihat besar hubungan antara faktor risiko yang diteliti dengan efek/kejadian gangguan koagulasi yang menggunakan skala nominal dilanjutkan regresi logistik berganda (Backward Wald) dengan syarat $\mathrm{p}<0,25$ pada uji bivariat. Uji statistik dianggap bermakna apabila nilai $\mathrm{p}<0,05$, rentang interval kepercayaan ditetapkan $95 \%$. Analisis statistik menggunakan software statistical package for social science (SPSS) versi 20.0 for windows. Penelitian telah mendapat persetujuan dari Komisi Etik Penelitian RS Dr. Kariadi dan RS Telogorejo. 


\section{Hasil}

Sejumlah 90 subyek memenuhi kriteria inklusi dan eksklusi dalam penelitian ini, dengan karakteristik subyek responden adalah sebagai berikut:

Tabel 1 menunjukkan karakteristik subjek dan Ibu pada kelompok kasus (pemanjangan studi koagulasi) dan kelompok kontrol (studi koagulasi normal). Karakteristik umur ibu, pekerjaan ibu, jenis kelamin bayi, persalinan, berat lahir dan kondisi pulang pada kelompok kasus dan kontrol tidak menunjukkan adanya perbedaan bermakna $(p>0,05)$.

Tabel 2 menunjukkan bahwa data PT dan PTTK terdistribusi tidak normal sehingga untuk uji hipotesis PT dan PTTK menggunakan uji non parametrik Mann Whitney. Tabel 3 menunjukkan kadar PT dan PTTK pada kelompok kasus lebih tinggi secara bermakna dari nilai rujukan sedangkan kelompok kontrol berada dalam rentang batas normal $(\mathrm{p}=0,001)$.

Tabel 4 menunjukkan bahwa preeklampsia dan KMK merupakan faktor risiko yang signifikan secara statistik terhadap kejadian pemanjangan PT dan PTTK $(\mathrm{p}=0,018, \mathrm{p}=0,042)$. Peningkatan risiko preeklampsia terhadap pemanjangan PT dan PTTK sebesar 4,26 kali $(\mathrm{p}=0,018)$, sedangkan risiko KMK terhadap kejadian pemanjangan studi koagulasi sebesar 4,52 kali $(\mathrm{p}=0,042)$. Faktor risiko maternal korioamnionitis, obat antikonvulsan atau antikoagulan yang dikonsumsi serta faktor neonatal bayi kurang bulan, asfiksia, sepsis dan penyakit hati secara statistik tidak merupakan faktor risiko terhadap kejadian pemanjangan studi koagulasi PT dan PTTK. Tabel 5 menunjukkan analisis multivariat dengan metode Backward Wald. Variabel yang paling berpengaruh terhadap kejadian risiko pemanjangan studi koagulasi adalah preeklampsia ( $\mathrm{RO} 4,629 ; \mathrm{p}=0,013)$.

\section{Pembahasan}

Pada preeklampsia, terjadi vasokonstriksi vasa uteroplasenta, hipoksia kronis sehingga terjadi disfungsi sel endotel mengakibatkan agregasi sel trombosit daerah endotel yang luka, terjadi peningkatan faktor koagulasi. ${ }^{12}$ Pada penelitian ini terdapat rerata peningkatan PT dan PTTK. Dengan uji bivariat chi square, preeklampsia

Tabel 1. Karakteristik subjek penelitian pada kelompok kasus dan kelompok kontrol

\begin{tabular}{|c|c|c|c|}
\hline \multirow[b]{2}{*}{ Variabel } & \multicolumn{2}{|c|}{ Kelompok (\%) } & \multirow[t]{2}{*}{$\mathrm{p}$} \\
\hline & Kasus $(n=45)$ & Kontrol $(n=45)$ & \\
\hline \multicolumn{4}{|l|}{ Umur ibu (tahun) } \\
\hline$<25$ & $4(8,9)$ & $0(0)$ & $0,084^{*}$ \\
\hline $25-35$ & $36(80)$ & $42(93,3)$ & \\
\hline$>35$ & $5(11,1)$ & $3(6,7)$ & \\
\hline \multicolumn{4}{|l|}{ Pekerjaan Ibu } \\
\hline Pegawai swasta & $15(33,3)$ & $7(15,6)$ & $0,116^{*}$ \\
\hline Wiraswasta & $11(24,4)$ & $11(24,4)$ & \\
\hline Ibu rumah tangga & $19(42,2)$ & $27(60)$ & \\
\hline \multicolumn{4}{|l|}{ Jenis kelamin bayi } \\
\hline Laki-laki & $26(57,7)$ & $28(62,2)$ & $0,667^{*}$ \\
\hline Perempuan & $19(42,2)$ & $17(37,7)$ & \\
\hline \multicolumn{4}{|l|}{ Persalinan } \\
\hline Spontan & $21(46,6)$ & $21(46,6)$ & $0,350^{*}$ \\
\hline Sectio Caesarea & $24(53,3)$ & $24(53,3)$ & \\
\hline Vakum & $2(4,4)$ & $0(0)$ & \\
\hline \multicolumn{4}{|l|}{ Berat Lahir (gr) } \\
\hline$<1500$ & $10(22,2)$ & $6(13,3)$ & $0,107^{*}$ \\
\hline $1500-2500$ & $18(40)$ & $12(26,7)$ & \\
\hline$>2500$ & $17(37,8)$ & $27(60)$ & \\
\hline \multicolumn{4}{|l|}{ Kondisi pulang } \\
\hline Hidup & $37(82,2)$ & $41(91,1)$ & $0,215^{*}$ \\
\hline Meninggal & $8(17,8)$ & $4(8,9)$ & \\
\hline
\end{tabular}


Tabel 2. Uji normalitas kadar PT dan PTTK pada kelompok kasus dan kontrol

\begin{tabular}{lcc}
\hline Variabel Kelompok & & $\mathrm{p}^{*}$ \\
\hline PT & Kasus & 0,026 \\
& Kontrol & 0,000 \\
PTTK & Kasus & 0,002 \\
& Kontrol & 0,074 \\
\hline
\end{tabular}

*Uji Kolmogorov Smirnov

Tabel 3. Rerata kadar PT dan PTTK pada kelompok kasus dan kontrol

\begin{tabular}{lccccccc}
\hline & Rerata & Simpang baku & Median & Minimal & Maksimal & Nilai rujukan & P \\
\hline Kadar PT & & & & & & & \\
$\quad$ Kasus & 15,14 & 3,14 & 14,20 & 11,75 & 28,00 & $9,40-11,7$ & $0,001^{\S}$ \\
$\quad$ Kontrol & 10,45 & 0,52 & 10,00 & 9,40 & 11,00 & & \\
Kadar PTTK & & & & & & & \\
$\quad$ Kasus & 58,89 & 16,56 & 55,10 & 40,50 & 125 & $24,6-30,6$ & $0,001^{\S}$ \\
$\quad$ Kontrol & 29,40 & 1,13 & 29,90 & 25,10 & 30,5 & & \\
\hline
\end{tabular}

${ }^{\S}$ Uji Mann-Whitney

Tabel 4. Hubungan antara faktor risiko dengan pemanjangan studi koagulasi

\begin{tabular}{|c|c|c|c|c|c|}
\hline Faktor risiko & Pemanjangan studi koagulasi & Studi koagulasi normal & $\mathrm{RO}$ & IK 95\% & $\mathrm{p}$ \\
\hline \multicolumn{6}{|l|}{ Preeklampsia } \\
\hline $\mathrm{Ya}$ & $14(31,1 \%)$ & $4(8,9 \%)$ & 4,26 & $1,38-15,44$ & $0,018^{*}$ \\
\hline Tidak & $31(68,9 \%)$ & $41(91,1 \%)$ & & & \\
\hline \multicolumn{6}{|c|}{ Korioamnionitis } \\
\hline $\mathrm{Ya}$ & $12(26,7 \%)$ & $8(17,8 \%)$ & 1,68 & $0,61-4,61$ & $0,447^{*}$ \\
\hline Tidak & $33(73,3 \%)$ & $37(82,2 \%)$ & & & \\
\hline \multicolumn{6}{|l|}{ Obat } \\
\hline $\mathrm{Ya}$ & $5(11,1 \%)$ & $0(0 \%)$ & - & - & $0,066^{*}$ \\
\hline Tidak & $40(88,9 \%)$ & $45(100 \%)$ & & & \\
\hline \multicolumn{6}{|l|}{ Gestasi } \\
\hline $\mathrm{BCB}$ & $23(51,1 \%)$ & $31(68,9 \%)$ & 2,11 & $0,89-5,00$ & $0,132^{*}$ \\
\hline $\mathrm{BKB}$ & $22(28,9 \%$ & $14(31,1 \%)$ & & & \\
\hline \multicolumn{6}{|l|}{ KMK } \\
\hline Ya & $11(24,4 \%)$ & $3(6,7 \%)$ & 4,52 & $1,16-17,54$ & $0,042^{*}$ \\
\hline Tidak & $34(75,6 \%$ & $42(93,3 \%)$ & & & \\
\hline \multicolumn{6}{|l|}{ Asfiksia } \\
\hline Ya & $26(57,8 \%)$ & $18(40 \%)$ & 2,05 & $0,88-4,75$ & $0,140^{*}$ \\
\hline Tidak & $19(42,2 \%)$ & $27(60 \%)$ & & & \\
\hline \multicolumn{6}{|l|}{ Sepsis } \\
\hline $\mathrm{Ya}$ & $15(33,3 \%)$ & $15(33,3 \%)$ & 1,00 & $0,41-2,40$ & $1,000^{*}$ \\
\hline Tidak & $30(66,7 \%)$ & $30(66,7 \%)$ & & & \\
\hline \multicolumn{6}{|l|}{ Penyakit hati } \\
\hline $\mathrm{Ya}$ & $5(11,1 \%)$ & $4(8,9 \%)$ & 1,28 & $0,32-5,11$ & $1,000^{*}$ \\
\hline Tidak & $40(88,9 \%)$ & $41(91,1 \%)$ & & & \\
\hline
\end{tabular}

Keterangan *Uji chi-square 
Tabel 5. Analisis multivariat

\begin{tabular}{|c|c|c|c|c|c|c|}
\hline & Variabel & B & Wald & $\mathrm{p}$ & $\mathrm{RO}$ & IK 95\% \\
\hline \multirow[t]{6}{*}{ Langkah 1} & Preeklampsia & 1,076 & 2,591 &, 107 & 2,933 & ,791-10,868 \\
\hline & KMK & $-1,238$ & 2,780 & 095 & ,290 & ,068-1,243 \\
\hline & Obat & 21,037 &, 000 & 999 & $1,4 \mathrm{E}+09$ & ,000-. \\
\hline & Gestasi &, 425 &, 544 & ,461 & 1,529 & ,495-4,727 \\
\hline & Asfiksia & ,290 & ,263 & ,608 & 1,336 & ,442-4,039 \\
\hline & Konstanta & 1,697 & 1,401 & ,237 & 5,458 & \\
\hline \multirow[t]{5}{*}{ Langkah 2} & Preeklampsia & 1,120 & 2,881 & ,090 & 3,066 & ,841-11,178 \\
\hline & KMK & $-1,285$ & 3,187 & ,074 & ,277 & $, 067-1,134$ \\
\hline & Gestasi &, 431 &, 575 & ,448 & 1,539 & $, 505-4,694$ \\
\hline & Asfiksia & ,203 & ,131 & ,717 & 1,225 & ,408-3,676 \\
\hline & Konstanta & 1,918 & 1,872 & ,171 & 6,805 & \\
\hline \multirow[t]{4}{*}{ Langkah 3} & Preeklampsia & 1,161 & 3,180 & ,075 & 3,194 & 891-11,448, \\
\hline & KMK & $-1,299$ & 3,261 & -071 & ,273 & ,067-1,117 \\
\hline & Gestasi &, 545 & 1,316 & ,251 & 1,724 & ,680-4,373 \\
\hline & Konstanta & 1,990 & 2,053 & ,152 & 7,317 & \\
\hline \multirow[t]{3}{*}{ Langkah 4} & Preeklampsia & 1,347 & 4,556 & ,033 & 3,846 & $1,116-13,249$ \\
\hline & KMK & $-1,267$ & 3,138 & ,076 & ,282 & $, 069-1,144$ \\
\hline & Konstanta & 2,115 & 2,345 & , 126 & 8,286 & \\
\hline \multirow[t]{2}{*}{ Langkah 5} & Preeklampsia & 1,532 & 6,211 & ,013 & 4,629 & $1,387-15,448$ \\
\hline & Konstanta &,- 280 & 1,380 & , 240 & ,756 & \\
\hline
\end{tabular}

Keterangan: Analisis multivariat, Backward Wald

merupakan faktor risiko pemanjangan studi koagulasi. Setelah dilakukan uji multivariat dengan uji regresi logistik berganda, didapatkan preeklampsia merupakan faktor risiko paling berpengaruh menyebabkan pemanjangan PT dan PTTK dibandingkan dengan KMK. Bayi dari ibu preeklampsia memiliki risiko pemanjangan studi koagulasi 4,62 kali lebih besar. Penelitian Abdalla dkk ${ }^{13}$ sejalan dengan penelitian ini, rerata PT dan PTTK, lebih tinggi pada bayi dari ibu preeklampsia dibanding bayi normal. Pemanjangan PT dan PTTK terjadi karena ketidakseimbangan antara koagulasi dan fibrinolisis pada area vaskular terutama sirkulasi uteroplasenta. ${ }^{14}$ Pemanjangan PT terjadi lebih jelas pada BKB dari Ibu dengan preeklampsia berat dibanding preeklampsia sedang. Hal ini karena terdapat defisiensi faktor dependen vitamin $\mathrm{K}$ pada BKB. ${ }^{15}$

Korioamnionitis, adalah korion, amnion dan cairan ketuban terkena infeksi bakteri, merupakan komplikasi serius bagi ibu dan janin. ${ }^{16}$ Pada penelitian ini tidak didapatkan hubungan antara korioamnionitis dengan pemanjangan PT dan PTTK. Hal ini berbeda dengan penelitian oleh Poralla $\mathrm{dkk}^{8}$ yang melaporkan bahwa bayi dari ibu dengan korioamnionitis secara memiliki pemanjangan faktor II, VIII, X. Penurunan kadar faktor koagulasi pada bayi dari ibu dengan riwayat korioamnionitis diprediksikan akibat penurunan sintesis atau high turnover rate. Perbedaan hasil penelitian karena subjek penelitian Poralla $\mathrm{dkk}^{8}$ adalah bayi extremely preterm dengan gestasi ( $<27$ minggu), sedangkan bayi pada penelitian ini adalah BCB dan BKB.

Hey ${ }^{17}$ melaporkan bahwa bayi dari ibu yang minum fenobarbital atau fenitoin mengalami pemanjangan prothrombin saat lahir, tetapi tidak didapatkan klinis perdarahan pada bayi. Konsumsi antikoagulan berupa warfarin dalam 48-72 jam sebelum persalinan menyebabkan risiko perdarahan pada bayi. Pada penelitian ini hanya didapatkan 5 ibu yang mengonsumsi obat antikonvulsan atau antikoagulan. Jumlah subjek 
yang terbatas menyebabkan penelitian ini belum dapat membuktikan hubungan antara konsumsi obat antikoagulan atau antikonvulsan dan pemanjangan studi koagulasi pada bayi.

Berdasarkan pustaka, nilai faktor koagulasi pada BCB dan BKB tidak jauh berbeda, tetapi faktor dependen vitamin $\mathrm{K}$ lebih rendah pada bayi $<28$ minggu. Nilai faktor koagulasi pada BCB dan BKB telah banyak dilaporkan, tetapi terdapat berbagai variasi dari instrumen laboratorium dan reagen yang dipakai yang dapat memengaruhi hasil laboratorium. ${ }^{18}$ Pada penelitian ini BKB bukan merupakan faktor risiko pemanjangan PT dan PTTK. Salonvaara $\mathrm{dkk}^{9}$ melaporkan hasil serupa bahwa tidak terdapat perbedaan INR (international normalized ratio) dan PTTK antara BKB dan BCB, walaupun dilaporkan terdapat perbedaan nilai faktor II, V dan VII pada bayi gestasi 2427 minggu dengan bayi gestasi 34-36 minggu. ${ }^{9}$ Swarnim $\mathrm{dkk}^{10}$ melaporkan bahwa BKB berisiko mengalami perdarahan dibandingkan $\mathrm{BCB}$. Pada penelitian tersebut penyebab perdarahan terbanyak pada BKB adalah sepsis dengan Disseminated Intravascular Coagulation (DIC). Bayi kurang bulan yang sakit berisiko menjadi DIC karena sistem reticuloendothelial yang belum berkembang dengan baik, penurunan sintesis faktor koagulasi, risiko terjadinya hipoksia, asidosis, dan syok.

Kecil masa kehamilan (KMK) merupakan faktor risiko terjadinya pemanjangan studi koagulasi. Hal ini sejalan dengan penelitian sebelumnya oleh Salonvaara $\mathrm{dkk}^{9}$ yang mendeteksi penurunan pada faktor $\mathrm{V}$ dan faktor VII pada bayi KMK dibandingkan SMK. Abdollahi dkk ${ }^{19}$ melaporkan bahwa terdapat perbedaan nilai PTTK antara BKB sehat dengan KMK dan SMK. Selain PTTK, terdapat perbedaan protein $S$ antara KMK dan SMK. Mitsiakos dkk ${ }^{20}$ melaporkan bahwa kadar fibrinogen lebih rendah pada BKB dengan KMK dibandingkan BKB SMK. Penelitian lain oleh Hannam $\mathrm{dkk}^{21}$ melaporkan bahwa terdapat pemanjangan INR pada KMK dibandingkan SMK. Pemeriksaan INR menggunakan reagen Dade-Innovin, INR $>1,5$ masuk dalam kategori abnormal. Bayi KMK berisiko mengalami gangguan koagulasi berupa penurunan faktor koagulasi dependen vitamin $\mathrm{K}$ dan trombositopenia. Bayi dengan restriksi pertumbuhan mengalami hipoksia intrauterin yang menyebabkan gangguan fungsi koagulasi pada liver.

Salonvaara $\mathrm{dkk}^{9}$ melaporkan bahwa bayi asfiksia dengan skor APGAR $<7$ pada menit ke- 5 mengalami pemanjangan studi koagulasi berupa faktor II, V, VII,
$\mathrm{X}$, dan pemanjangan prothrombin, sedangkan partial thomboplastin time tidak memanjang. Studi lain oleh Murthy $\mathrm{dkk}^{22}$ melaporkan bahwa bayi dengan asfiksia berat (skor APGAR $<7$ pada menit ke- 5) mengalami pemanjangan PTTK (pemanjangan jika nilai lebih besar dari kontrol). Chad $\mathrm{dkk}^{23}$ melaporkan bahwa bayi dengan asfiksia memiliki rerata nilai koagulasi (thrombin clotting time dan kaolin cephalin clotting time) lebih rendah dibanding bayi sehat. Peneliti juga melaporkan hubungan antara derajat asfiksia dengan abnormalitas studi koagulasi. Alat dan reagen tidak dilaporkan pada jurnal. Pada penelitian ini tidak terbukti bahwa asfiksia merupakan faktor risiko pemanjangan studi koagulasi. Derajat asfiksia pada penelitian ini bervariasi dari ringan sampai berat, hal ini yang menyebabkan asfiksia tidak terbukti sebagai faktor risiko pemanjangan studi koagulasi.

Sepsis tidak terbukti sebagai faktor risiko pemanjangan PT dan PTTK. Pada sepsis awitan dini atau sepsis yang tidak berkomplikasi maka PT dan PTTK masih normal. Pada sepsis berat dengan komplikasi DIC atau syok septik terjadi pemanjangan PT dan PTTK. ${ }^{24}$ Pada penelitian ini tidak dijumpai bayi yang menderita DIC atau sakit berat, baik pada kelompok kasus maupun kelompok kontrol. Mitra $\mathrm{dkk}^{24}$ melaporkan bayi sepsis mengalami pemanjangan PT dan PTTK dibanding bayi normal. Selain PT dan PTTK terdapat peningkatan fibrinogen pada bayi sepsis dibanding bayi normal.

Penyakit hati bukan merupakan faktor risiko pemanjangan studi koagulasi. Hal ini dapat disebabkan subjek penelitian yang terbatas dan jumlah subjek pada kasus (5 subjek) dan kontrol (4 subjek) yang tidak jauh berbeda. Saxonhouse $\mathrm{dkk}^{25}$ melaporkan bahwa penyakit hati atau gagal hati akut jarang terjadi pada neonatus. Hal ini menyebabkan jumlah subjek sedikit pada penelitian.

\section{Kesimpulan}

Ibu preeklampsia dan Bayi KMK merupakan faktor risiko terhadap pemanjangan PT dan PTTK pada neonatus. Ibu preeklampsia juga merupakan faktor risiko yang paling kuat berpengaruh terhadap pemanjangan PT dan PTTK (4,629 kali), dibandingkan bayi KMK. Saran untuk penelitian selanjutnya adalah deteksi awal/ skrining pada bayi baru lahir dengan faktor risiko gangguan koagulasi (PT dan PTTK) dan penelitian mengenai masing - masing faktor risiko terhadap gangguan faktor koagulasi. 


\section{Daftar pustaka}

1. Gomella TL, Cunningham MD EF. Coagulation disorders. Dalam: Gomella TL, Cunningham MD EF, penyunting. Neonatology management, procedures, on-call probles, diseases, and drugs. Edisi ke-7. United States: Mc Graw Hill; 2013.h.584-94.

2. Acharya SS SS. Disorders of coagulation. Dalam: Lanzkowsky P, Lipton JM FJ, penyunting. Lanzkowsky's Manual of Pediatric. Edisi ke-6. United States: Academic Press; 2016.h.284-5.

3. Davila J. Coagulation disorders in the newborn. Neoreviews 2018;19:11-21.

4. de Alarcón PA, Werner EJ. Neonatal hematology. Neonatal Hematol 2005;22:1-452.

5. Sarnaik A, Kamat D. Diagnosis and management of bleeding disorder in a child. Clin Pediatr 2010;49:422-8.

6. Maduhu I, Manji KP MR. Perinatal risk factors for neonatal bleeding at the Muhimbili National Hospital. Tanzania Med J 2004;19:1-3.

7. Manco-Johnson MJ. Bleeding disorders in the neonate. Neoreviews 2008;9:e162-9.

8. Poralla C, Traut C, Hertfelder HJ, Oldenburg J, Bartmann P, Heep A. The coagulation system of extremely preterm infants: Influence of perinatal risk factors on coagulation. J Perinatol 2012;32:869-73.

9. Salonvaara M, Riikonen P, Kekomäki R, dkk. Effects of gestational age and prenatal and perinatal events on the coagulation status in premature infants. Arch Dis Child Fetal Neonatal Ed 2003;88:F319-23.

10. Swarnim S, Rai BK, Divya M, Kripanath M. A prospective study of bleeding neonates: Clinical presentation, aetiological profile, immediate outcome and short term follow up. Curr Pediatr Res 2017;21:416-9.

11. Kochanek KD, Xu J, Murphy SL, Minino AM, Kung H-C. National vital statistics reports - deaths: final data for 2013. Natl Cent Heal Stat 2013;64:1-117.

12. Tanjung MT, Siddik HD, Hariman H, Koh SCL. Coagulation and fibrinolysis in preeclampsia and neonates. Clin Appl Thromb 2005;11:467-73.
13. Abdalla M, Sayed E, Ahmed A. Assessment of the hematological profile in neonates born to severe pre eclamptic mothers (single center study). Int J Pregn Chi Birth 2018;4:214-8.

14. Mosayebi Z, Nariman S, Hosseini L, Movahedian AH. Evaluation of laboratory disorders in admitted neonates in NICU who were born to preeclamptic mothers evaluation of laboratory disorders in admitted neonates in NICU who were born to preeclamptic mothers. J Compr Ped 2013;3:194-8.

15. Narayan S, Mangwana S, Kabra M. Consumption coagulopathy in neonates born to mothers with pregnancy induced hypertension. Indian Pediatr 1994;31:4-7.

16. Pugni L, Pietrasanta C, Acaia B, dkk. Chorioamnionitis and neonatal outcome in preterm infants : a clinical overview. J Matern Neonatal Med 2015;00:1-5.

17. Hey E. Effect of maternal anticonvulsant treatment on neonatal blood coagulation. Arch Dis Child Fetal Neonatal 1999;81:208-210.

18. Monagle P, Barnes C, Ignjatovic V, dkk. Developmental hemostasis impact for clinical haemostasis laboratories. Thromb Haemost 2006;95:362.

19. Abdollahi A, Sheikhbahaei S, Hafezi-nejad N, Mahdaviani B. Hemostatic profile in healthy premature neonates; does birth weight affect the coagulation profile? J Clin Neonatol 2014;3:89-91.

20. Mitsiakos G, Giougi E, Chatziioannidis I, dkk. Haemostatic profile of healthy premature small for gestational age neonates. Thromb Res 2010;126:103-6.

21. Hannam S, Edwards RJ. Neonatal coagulopathy in preterm, small-for-gestational-age infants. Biol Neonate 2003;83:177-81.

22. Murthy S, Krishnamurthy V. Coagulation profile in perinatal asphyxia. Int J Pediatr 2015;2:64-8.

23. Chad MA, Elwood PC, Gray P. Muxworthy SM. Coagulation defects in hypoxic full-term newborn infants. Br Med J 1971;4:516-8.

24. Mitra P,Guha D, Nag SS, Mondal BC. Role of plasma fibrinogen in diagnosis and prediction of short term outcome in neonatal sepsis. Indian J Hematol Blood Transfus 2017;33:195-9.

25. Saxonhouse MA, Manco-Johnson MJ. The evaluation and management of neonatal coagulation disorders. Semin Perinatol 2009;33:52-6. 